\title{
Curcumin reverses chemoresistance of human gastric cancer cells by downregulating the $\mathrm{NF}-\kappa \mathrm{B}$ transcription factor
}

\author{
LIANG-LIANG YU ${ }^{1}$, JIA-GUO WU ${ }^{1}$, NING DAI ${ }^{1}$, HONG-GANG YU ${ }^{2}$ and JIAN-MIN SI ${ }^{1}$ \\ ${ }^{1}$ Department of Gastroenterology, Sir Run Run Shaw Hospital Affiliated Hospital of \\ Zhejiang University, Key Laboratory of Biotherapy of Zhejiang Province, Hangzhou 310016; \\ ${ }^{2}$ Department of Gastroenterology, Renmin Hospital of Wuhan University, Wuhan 430060, P.R. China
}

Received June 22, 2011; Accepted July 13, 2011

DOI: $10.3892 /$ or.2011.1410

\begin{abstract}
Gastric cancer remains one of the major health problems worldwide. Chemotherapy is an important therapeutic modality for gastric cancer, but the success rate of this treatment is limited because of chemoresistance. The ubiquitously expressed transcription factor $\mathrm{NF}-\kappa \mathrm{B}$ has been suggested to be associated with chemoresistance of gastric cancer. Agents that can either enhance the effects of chemotherapeutics or overcome chemoresistance to chemotherapeutics are needed for the treatment of gastric cancer. Curcumin, a component of turmeric, is one such agent that has been shown to suppress $\mathrm{NF}-\kappa \mathrm{B}$ and increase the efficacy of chemotherapy. In this study, we investigated whether curcumin can reverse chemoresistance by downregulating $\mathrm{NF}-\kappa \mathrm{B}$ in human gastric cancer cells. SGC-7901 human gastric cancer cells was treated with chemotherapeutics (etoposide and doxorubicin) or by combined application of curcumin and chemotherapeutics. The viability of SGC-7901 cells was measured by MTT assay. Apoptosis of SGC-7901 cells was detected using the TUNEL and Annexin V/PI methods. The protein levels of NF- $\kappa \mathrm{B}$ were analyzed by immunocytochemical staining. EMSA was used to confirm the increased nuclear translocation of RelA. The protein levels of $\mathrm{p}-\mathrm{I} \kappa \mathrm{B} \alpha, \mathrm{Bcl}-2$ and Bcl-xL were analyzed by Western blotting. The chemotherapeutics (etoposide and doxorubicin) suppressed the growth of SGC-7901 cells, in a time-dose-dependent manner. Use of curcumin in addition to these agents can suppress cell growth further (inhibitory rate: doxorubicin vs. doxorubicin + curcumin, $33 \%$ vs. $45 \%, \mathrm{p}<0.05$; etoposide vs. etoposide + curcumin, $35 \%$ vs. $48 \%$, p<0.05). Furthermore, chemotherapeutics induced apoptosis of SGC-7901 cells and activated NF- $\mathrm{BB}$. The combination of curcumin and chemotherapeutics induced apoptosis of SGC-7901 cells further, attenuated the activation
\end{abstract}

Correspondence to: Dr Liang-Liang Yu and Dr Jia-Guo Wu, Department of Gastroenterology, Sir Run Run Shaw Affiliated Hospital of Zhejiang University, 3 East Qingchun Road, Hangzhou 310016, Zhejiang, P.R. China

E-mail: yuliangliang@sina.com.cn ydycn08@yahoo.com.cn

Key words: curcumin, NF-кB, gastric cancer cell, chemotherapy of $\mathrm{NF}-\kappa \mathrm{B}$, and reduced expression of the $\mathrm{NF}-\kappa \mathrm{B}-$ regulated anti-apoptotic gene products $\mathrm{Bcl}-2$ and $\mathrm{Bcl}-\mathrm{xL}$. Curcumin potentiates the antitumor effects of chemotherapeutics in gastric cancer by suppressing $\mathrm{NF}-\kappa \mathrm{B}$ and $\mathrm{NF}-\kappa \mathrm{B}-$ regulated anti-apoptotic genes.

\section{Introduction}

Gastric cancer remains one of the major health problems worldwide, and it is one of the most common cancers and the leading cause of cancer-related deaths in China. Chemotherapy is an important therapeutic modality for gastric cancer besides surgical resection, although the success rate of this treatment is limited because of chemoresistance. Thus, there is a need for novel strategies involving less toxic agents that can sensitize gastric cancer cells to chemotherapy. The rationale of anticancer chemotherapy relies mainly on DNA damaging insults in rapidly dividing tumor cells, imposing a strong apoptotic trigger. However, some tumor cells can obtain chemoresistance through adjusting some survival signal transduction pathway. Therefore, the efficacy of chemotherapeutics is severely limited because of chemoresistance. Several studies have suggested that the transcription factor $N F-\kappa B$ is the key molecule for protecting cells from undergoing apoptosis, and that $\mathrm{NF}-\kappa \mathrm{B}$ mediated survival signaling pathway associate with chemoresistance of human tumors (1-3).

The nuclear transcription factor $\kappa \mathrm{B}(\mathrm{NF}-\kappa \mathrm{B})$ is a pleiotropic activator that participates in the induction of a wide variety of cellular genes. In addition to its role in inflammation and immune response, $\mathrm{NF}-\kappa \mathrm{B}$ has also been implicated in the suppression of apoptosis, cellular survival, transformation, and oncogenesis $(4,5)$. In the field of oncology, NF- $\kappa \mathrm{B}$ has been shown to be constitutively active in numerous neoplasms $(6,7)$. Chemotherapy agents have been shown to induce NF- $\kappa B$, furthermore, the activation of NF- $\mathrm{NB}$ has been suggested to associate with chemoresistance of human tumors. More specifically, inhibiting $\mathrm{NF}-\kappa \mathrm{B}$ activation in response to chemotherapy significantly enhanced the cytotoxic effects of chemotherapeutics. This relationship has been reported in a variety of cancer cell types. Several reports have shown that NF- $\kappa$ B plays a critical role in promoting cell proliferation and inhibiting cell death, and the increased activity of NF- $\kappa \mathrm{B}$ could be directly or indirectly related to the resistance to chemotherapy $(8,9)$. 
Curcumin is a natural phenolic coloring compound that is found in the rhizomes of curcuma, commonly called turmeric. It has been widely used as a spice, to color cheese and butter, as a cosmetic, and in some medicinal preparations. Curcumin has a wide range of biological and pharmacological activities $(10,11)$, including antioxidant properties, anti-inflammatory properties, anti-mutagenic activity, and anti-carcinogenic. The safety of curcuma and its derivatives has been studied in various animal models, and it is clear that turmeric is not toxic even at high doses in laboratory animals $(10,11)$. Curcumin has been shown to suppress NF- $\kappa \mathrm{B}$ activation (12) and downregulate the expression of $\mathrm{NF}-\kappa \mathrm{B}-$ regulated gene products with roles in anti-apoptosis, such as Bcl-2 and Bcl-xL. Thus, the present study was undertaken to elucidate the role of $\mathrm{NF}-\kappa \mathrm{B}$ pathway in the development of chemoresistance in gastric cancer, and whether curcumin can potentiate the antitumor effects of chemotherapeutics against gastric cancer cells by downregulating $\mathrm{NF}-\kappa \mathrm{B}$.

\section{Materials and methods}

Materials and reagents. Etoposide and doxorubicin were purchased from Alexis Biochemicals. Curcumin was purchased from Sigma Biochemicals. The mouse monoclonal antibodies against $\mathrm{NF}-\kappa \mathrm{B} / \mathrm{p} 65, \mathrm{Bcl}-2$ and $\mathrm{Bcl}-\mathrm{xL}$ were purchased from Santa Cruz Biotechnology. The mouse monoclonal antibody against pospho-I $\kappa \mathrm{B} \alpha$ and Western blot assay kit were purchased from Cell Signal Tech. The EMSA assay kit was purchased from Promega. The TUNEL and Annexin V/PI assay kits were purchased from Roche.

Cell culture. The human gastric cancer cell line SGC7901 was obtained from Shanghai Institute of Cell Biology, Chinese Academy of Sciences, and maintained at $37^{\circ} \mathrm{C}$ in RPMI-1640 medium, supplemented with $10 \%$ fetal bovine serum and $100 \mathrm{U} / \mathrm{ml}$ penicillin and $100 \mathrm{mg} / \mathrm{ml}$ streptomycin in a humidified atmosphere containing $5 \% \mathrm{CO}_{2}$ and $95 \%$ air. For experimental purposes, cells were plated in $35-\mathrm{mm}$ dishes at $1 \times 10^{6}$ cells/dish and grown in RPMI-1640 medium for 5-7 days.

MTT assay. Cultured cells were plated at a density of $4 \times 10^{3}$ cells/ well on a 96-well plate. At $24 \mathrm{~h}$ after seeding, various concentrations of chemotherapeutics or curcumin (doxorubicin: 0 , 0.03, 0.3, $3 \mu \mathrm{mol} / 1$; etoposide: 0, 2, 20, $200 \mu \mathrm{mol} / 1$; curcumin: $0,10,20,40,80,160 \mu \mathrm{mol} / \mathrm{l}$ ) were added to the culture medium. Combined use of chemotherapeutics and curcumin, requires pretreatment by curcumin $(40 \mu \mathrm{mol} / \mathrm{l})$ for $2 \mathrm{~h}$. Then various concentrations of chemotherapeutics (as above) were added to the culture medium. Viability of cells at $0,3,6,12,24 \mathrm{~h}$ after drug treatment was evaluated by the MTT assay. Controls were treated with DMSO vehicle at a concentration equal to that in drug-treated cells. MTT [3-(4,5-dimethylthiazol-2-yl)2,5-diphenyltetrazolium bromide] was added to each well at a concentration of $500 \mu \mathrm{g} / \mathrm{ml}$, and plates were incubated for $4 \mathrm{~h}$ at $37^{\circ} \mathrm{C}$. After $4 \mathrm{~h}$, media were aspirated, cells were lysed with $400 \mu \mathrm{l}$ DMSO. Cells were incubated for a further $10 \mathrm{~min}$ at $37^{\circ} \mathrm{C}$ with gentle shaking. Absorbance readings at $570 \mathrm{nM}$ were determined using a computer-controlled microplate analyzer. The inhibitory rate (\%) is calculated using following equation: Inhibitory rate $(\%)=\left(1-\mathrm{OD}_{\mathrm{A}} / \mathrm{OD}_{\mathrm{C}}\right) \times 100$, where $\mathrm{OD}_{\mathrm{A}}$, the OD value of group with treatment of drugs; $\mathrm{OD}_{\mathrm{C}}$ the $\mathrm{OD}$ value of group without treatment of drugs.

Immunocytochemistry. Cultured cells were seeded on slides. At $24 \mathrm{~h}$ after seeding, various concentrations of chemotherapeutics (as above) were added to the culture medium. For combined use of chemotherapeutics and curcumin, cells was pretreated by curcumin $(40 \mu \mathrm{mol} / \mathrm{l})$ for $2 \mathrm{~h}$. Then various concentrations of chemotherapeutics (doxorubicin: $0.3 \mu \mathrm{mol} / \mathrm{l}$; etoposide: $20 \mu \mathrm{mol} / \mathrm{l}$ ) were added to the culture medium. Immunostaining was performed as per the kit manual. In specimens containing positive cells, the positive cells were counted in ten randomly selected fields under 200- or 400-fold magnification for each sample, and the average was expressed as the density of positive cells.

Terminal deoxynucleotidyl transferase-mediated nick endlabeling (TUNEL). The drug intervention was the same as above. Apoptosis of SGC-7901 were detected by TUNEL, and TUNEL staining was carried out according to TUNEL assay kit manual. Positive signals were defined as presence of a distinct brown color nuclear staining of the cancer cells or morphologically defined apoptotic bodies. The apoptotic index (AI) was determined by counting a total of at least 1,000 cells nuclei in 10 randomly chosen fields at 200- or 400-fold magnification.

Annexin V/PI staining. The drug intervention was the same as above. Cells suspended at each chosen time point after various concentrations of anticancer treatment were fixed with ice-cold $75 \%$ ethanol, washed twice with PBS, and incubated in $20 \mu \mathrm{g} / \mathrm{ml}$ RNase A for $30 \mathrm{~min}$ at $37^{\circ} \mathrm{C}$. Subsequently, cells were stained with Annexin-V-Fluorescein and propidium iodide (PI), and measured for DNA content by flow cytometry (Becton Dickinson, Helmetta, NJ).

Electrophoretic mobility shift assay. The drug intervention was the same as above. Nuclear extracts were harvested according to protocols described previously (13). The protein concentrations of nuclear extracts were determined by Bio-Rad protein assay. Nuclear protein extracts were analyzed by EMSA for $\mathrm{NF}-\kappa \mathrm{B}$ nuclear translocation as previously described $(14,15)$. Nuclear extracts were incubated with a $\gamma^{-}{ }^{32} \mathrm{P}$-labeled oligonucleotide (5'-AGTTGAGGGGACTTTCCCAGGC-3') containing a consensus $\mathrm{NF}-\kappa \mathrm{B}$ binding site for $30 \mathrm{~min}$ at room temperature. For super-shift experiments, $2 \mu \mathrm{g}$ of mouse monoclonal antibody against the p65 subunit of $\mathrm{NF}-\kappa \mathrm{B}$ were incubated with the nuclear extracts $10 \mathrm{~min}$ before the addition of the $\gamma-{ }^{32} \mathrm{P}$ labeled probe and then analyzed. For specific competitor experiments, superfluous non-labeled probe were incubated with the nuclear extracts. Samples were electrophoresed at $100 \mathrm{~V}$ and $4^{\circ} \mathrm{C}$, and gels were dried and exposed to X-ray film (Kodak).

Immunoblot analysis. The drug intervention was the same as above. Cells were lysed in ice-cold lysis buffer (1X PBS, $1 \%$ Igepal CA-630, $0.5 \%$ sodium deoxycholate, $0.1 \%$ SDS, $10 \mathrm{mg} / \mathrm{ml}$ phenylmethylsulfonyl fluoride, $100 \mathrm{mM}$ sodium orthovanadate, $60 \mu \mathrm{g} / \mathrm{ml}$ aprotinin, $10 \mu \mathrm{g} / \mathrm{ml}$ trypsin inhibitor and $10 \mu \mathrm{g} / \mathrm{ml}$ leupeptin). After $10 \mathrm{~min}$ centrifugation at $10,000 \mathrm{x} \mathrm{g}$ at $4^{\circ} \mathrm{C}$, the supernatants were transferred into new microcentrifuge tubes 

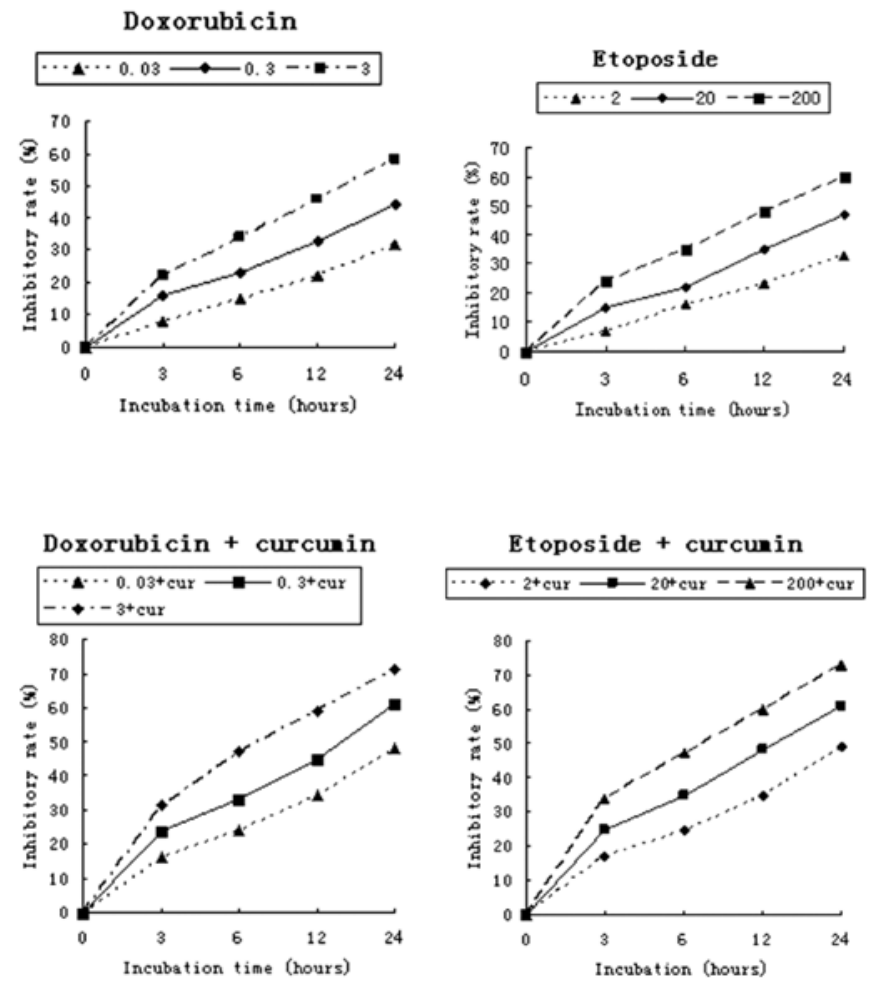

Figure 1. Effect of chemotherapeutics and combined use of curcumin (40 $\mu \mathrm{mol} / 1$ pretreatment) on growth of gastric cancer cells. An MTT assay was used to detect the growth of gastric cancer cells. Inhibitory rate was significantly increased and present time-dose-dependence $(\mathrm{p}<0.05$, Student's t-test). Combined use of curcumin can suppress cell growth further than chemotherapeutics $(\mathrm{p}<0.05$, Student's t-test).

and the protein concentration of the supernatant was measured using BCA protein assay. Then stored at $-20^{\circ} \mathrm{C}$. Cell lysates $(50 \mu \mathrm{g})$ was separated on SDS-PAGE gel. Following SDS-PAGE, proteins were transferred to nitrocellulose membranes. For detection of proteins, membranes were blocked using 5\% nonfat dried milk in Tris buffer containing $0.1 \%$ Tween (TBS-T). Next incubated at $4^{\circ} \mathrm{C}$ overnight with anti-pospho-IкB $\alpha$ (1:1000), antiBcl-2 (1:1000), and anti-Bcl-xL (1:1000) antibodies diluted in TBS-T containing 5\% nonfat milk. Then subsequently with horseradish peroxidase conjugated anti-mouse antibody (1:2000). Peroxidase activity was visualized by enhanced chemiluminescence detection.

Statistical analysis. All experiments were repeated at least three times. Results are expressed as mean \pm standard deviation (SD). All statistical analyses were performed with SPSS12.0 statistical package for Microsoft Windows. Student's t-test was used to compare continuous variables among groups. A p-value of $<0.05$ was considered significant.

\section{Results}

Curcumin has no cytotoxic effect on the gastric cancer cell line SGC7901. We found that $1-40 \mu \mathrm{mol} / 1$ curcumin was not obviously cytotoxic to the gastric cancer cell line SGC7901 (survival rate $>90 \%$ ). However, 80-160 $\mu \mathrm{mol} / 1$ curcumin caused significant cytotoxicity in SGC7901. Since treatment of the cells with 10,20 , and $40 \mu \mathrm{mol} / 1$ curcumin had no

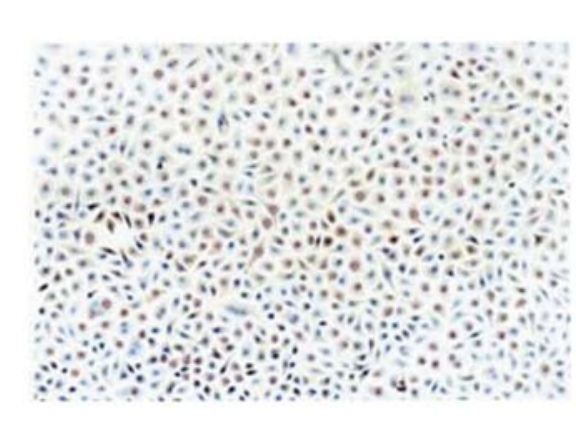

A

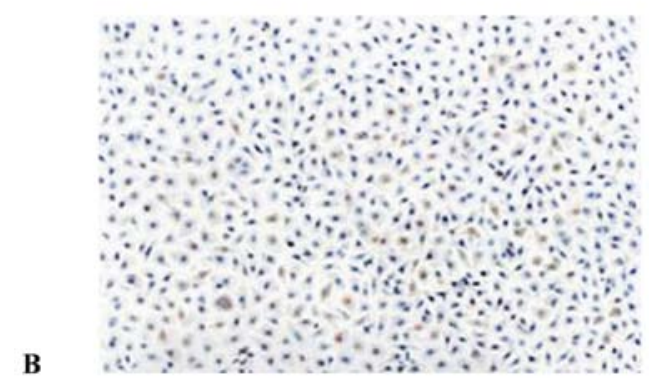

Figure 2. Immunocytochemical staining of NF- $\mathrm{B} / \mathrm{p} 65$. Positive staining of NF- $\mathrm{NB} / \mathrm{p} 65$ was observed in the cytoplasm and nuclear staining. (A) The $\mathrm{NF}-\kappa \mathrm{B} / \mathrm{p} 65$ expression in cells treated by doxorubicin $(0.3 \mu \mathrm{mol} / \mathrm{l})(\mathrm{x} 200)$. (B) The NF- $\kappa \mathrm{B} / \mathrm{p} 65$ expression in cells treated by doxorubicin $(0.3 \mu \mathrm{mol} / \mathrm{l})+$ curcumin (40 $\mu \mathrm{mol} / 1$ pretreatment) (x200).

significant effect on cell viability, we used these concentrations for further analysis.

Chemotherapeutics inhibit cell growth, jointly using curcumin inhibits cell growth further. To determine whether chemotherapeutics or jointly using curcumin inhibits the proliferation of the human gastric cancer SGC-7901 cells the viability was tested using an MTT assay after incubation with various concentrations of chemotherapeutics or jointly using curcumin. Etoposide or doxorubicin suppressed the growth of SGC-7901 obviously, jointly using curcumin suppressed its growth further (inhibitory rate: doxorubicin vs. doxorubicin + curcumin, 33 vs. $45 \%$, $\mathrm{p}<0.05$; etoposide vs. etoposide + curcumin, 35 vs. $48 \%$, $\mathrm{p}<0.05$ ) and present time-dose-dependence. However, the differences on the inhibitory rate between etoposide and doxorubicin were not statistically significant (Fig. 1).

Chemotherapeutics induce $N F-\kappa B / p 65$ expression, jointly using curcumin attenuates it expression. The MTT assay indicated growth of cells was inhibited strongly after chemotherapeutics or the combined use of inhibitor for 12-24 h. To avoid experimental errors, because the quantity of viable cells was relatively small we chose $12 \mathrm{~h}$ for this treatment time, and the drug concentration (doxorubicin, $0.3 \mu \mathrm{mol} / \mathrm{l}$; etoposide, $20 \mu \mathrm{mol} / \mathrm{l}$ ) in later experiments. $\mathrm{NF}-\kappa \mathrm{B} / \mathrm{p} 65$ protein expression was measured by immunocytochemical staining. Positive staining of $\mathrm{NF}-\kappa \mathrm{B} /$ p65 was observed in the cytoplasm and nuclear staining. Nuclear translocation of NF- $\kappa \mathrm{B}$ was considered positive if nuclear staining was predominant over cytoplasmic staining or if only nuclear staining was detected. The gastric cancer cells SGC-7901 showed basal NF- $\kappa$ B protein expression, which was significantly increased when exposed to etoposide or doxo- 


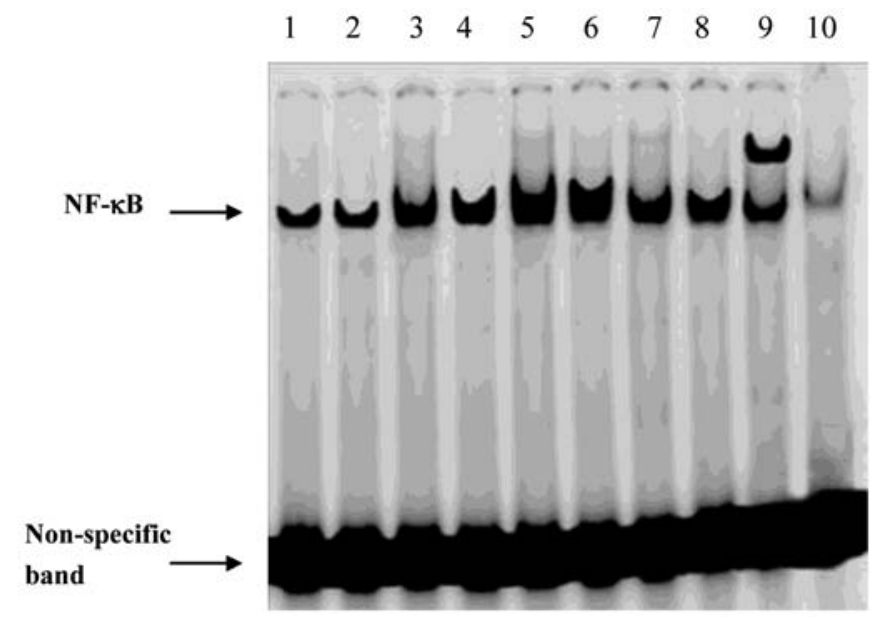

Figure 3. EMSA was used to detect NF-kB-DNA binding activity. The effect of chemotherapeutics and combined use of curcumin $(40 \mu \mathrm{mol} / \mathrm{l}$ pretreatment $)$ on NF-kB activity. Lane 1, etoposide $2 \mu \mathrm{mol} / 1$; lane 2, doxorubicin $0.03 \mu \mathrm{mol} / \mathrm{l}$; lane 3 , etoposide $20 \mu \mathrm{mol} / 1$; lane 4 , doxorubicin $0.3 \mu \mathrm{mol} / 1$; lane 5 , etoposide $200 \mu \mathrm{mol} / 1$; lane 6 , doxorubicin $3 \mu \mathrm{mol} / 1$; lane 7 , etoposide $(20 \mu \mathrm{mol} / 1)+$ curcumin; lane 8 , doxorubicin $(0.3 \mu \mathrm{mol} / \mathrm{l})+$ curcumin; lane 9 , super-shift experiments; lane 10 , specific competitor experiments.

A
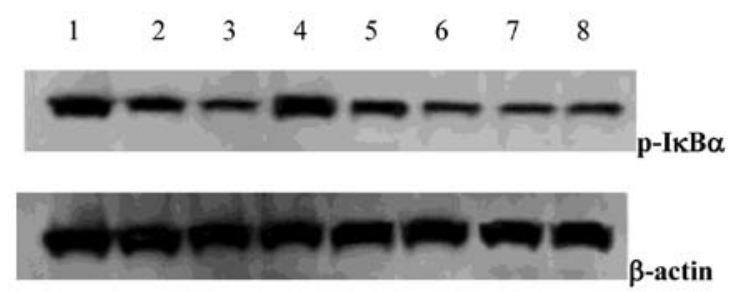

\section{B}

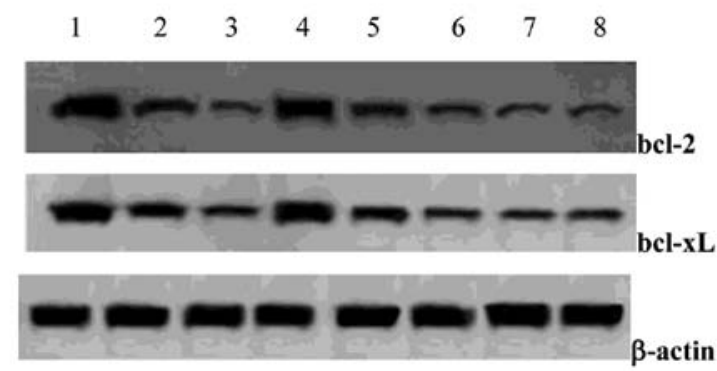

Figure 4. Immunoblot was used to detect $\mathrm{p}-\mathrm{I} \kappa \mathrm{B} \alpha, \mathrm{Bcl}-2$ and $\mathrm{Bcl}-\mathrm{xL}$. (A) The effect of etoposide, doxorubicin and combined use of curcumin ( $40 \mu \mathrm{mol} / 1$ pretreatment) on $\mathrm{p}-\mathrm{I \kappa B} \alpha$. Lane 1 , doxorubicin $3 \mu \mathrm{mol} / 1$; lane 2 , doxorubicin $0.3 \mu \mathrm{mol} / 1$; lane 3 , doxorubicin $0.03 \mu \mathrm{mol} / 1$; lane 4 , etoposide $200 \mu \mathrm{mol} / 1$; lane 5 , etoposide $20 \mu \mathrm{mol} / 1$; lane 6 , etoposide $2 \mu \mathrm{mol} / 1$; lane 7 , etoposide $(20 \mu \mathrm{mol} / 1)+$ curcumin; lane 8 , doxorubicin $(0.3 \mu \mathrm{mol} / 1)$ + curcumin. (B) The effect of etoposide, doxorubicin and combined use of curcumin $(40 \mu \mathrm{mol} / 1$ pretreatment) on Bcl-2, Bcl-xL. Lane 1, doxorubicin $3 \mu \mathrm{mol} / 1$; lane 2, doxorubicin $0.3 \mu \mathrm{mol} / 1$; lane 3, doxorubicin $0.03 \mu \mathrm{mol} / 1$ lane 4 , etoposide $200 \mu \mathrm{mol} / 1$; lane 5 , etoposide $20 \mu \mathrm{mol} / 1$; lane 6 , etoposide $2 \mu \mathrm{mol} / 1$; lane 7 , etoposide $(20 \mu \mathrm{mol} / 1)+$ curcumin; lane 8 , doxorubicin $(0.3 \mu \mathrm{mol} / \mathrm{l})+$ curcumin. Immunoblotting result of $\beta$-actin is used to show equal loading.

rubicin. Also, its expression was attenuated by jointly using curcumin (Fig. 2).

The effect of chemotherapeutics and jointly using curcumin on $N F-\kappa B-D N A$ binding activity. We found that etoposide or doxorubicin induced a dose-dependent increase in NF- $\kappa \mathrm{B}-\mathrm{DNA}$
A

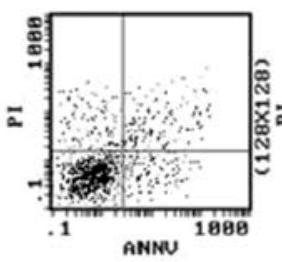

D

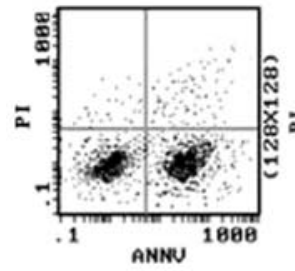

G
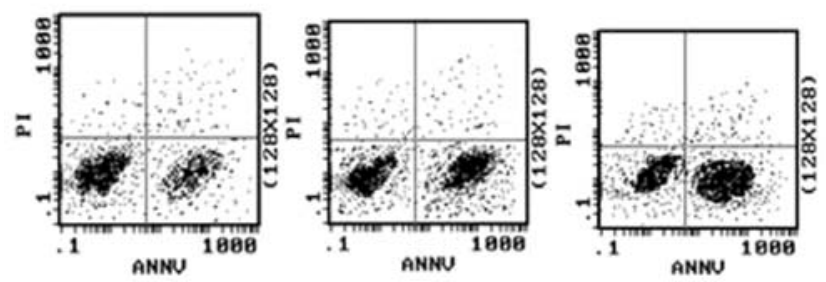

Figure 5. Annexin V/PI staining was used to detect apoptosis. Viable, apoptosis and necrosis cell phenotype: Annexin $\mathrm{V}^{-} / \mathrm{PI}^{-}$, Annexin $\mathrm{V}^{+} / \mathrm{PI}^{-}$, Annexin $\mathrm{V}^{+} / \mathrm{PI}^{+}$. (A) curcumin; (B) doxorubicin $0.03 \mu \mathrm{mol} / 1$; (C) doxorubicin $0.3 \mu \mathrm{mol} / 1$; (D) doxorubicin $3 \mu \mathrm{mol} / 1$; (E) doxorubicin $0.3 \mu \mathrm{mol} / 1+$ curcumin (40 $\mu \mathrm{mol} / 1$ pretreatment); (F) etoposide $2 \mu \mathrm{mol} / 1$; (G) etoposide $20 \mu \mathrm{mol} / \mathrm{l}$; (H) etoposide $200 \mu \mathrm{mol} / 1$; (I) etoposide $20 \mu \mathrm{mol} / 1+$ curcumin $(40 \mu \mathrm{mol} / 1 \mathrm{pre}-$ treatment). Apoptosis increased significantly induced by chemotherapeutics and combined use of curcumin and present time-dose-dependence $(\mathrm{p}<0.05$, Student's t-test).

binding activity. Jointly using curcumin can attenuate NF- $\kappa$ B-DNA binding activity (Fig. 3), similarly to the outcome of the immunocytochemical staining. To confirm the specificity of NF- $\mathrm{B}$-DNA binding, we performed super-shift analysis with antibody specific for p65 and a competitive study with a 50-fold excess of unlabeled oligonucleotides. An antibody specific for p65 which recognizes $\mathrm{NF}-\kappa \mathrm{B} / \mathrm{p} 65$ heterodimer, unlabeled oligonucleotide diminished the intensity of $N F-\kappa B /$ p65 complexes, indicating that the complex was the $\mathrm{NF}-\kappa \mathrm{B}$ binding-specific band.

The effect of chemotherapeutics and jointly using curcumin on phosphorylation of $I \kappa B \alpha$. The translocation of $N F-\kappa B$ to the nucleus is preceded by the phosphorylation, ubiquitination, and proteolytic degradation of $\operatorname{I} \kappa \mathrm{B} \alpha(4,6)$. To determine whether chemotherapeutics-induced $N F-\kappa B$ activation was due to I $\kappa \mathrm{B} \alpha$ degradation, we examined the cells for pospho-I $\kappa \mathrm{B} \alpha$ by Western blotting. The etoposide or doxorubicin increased the phosphorylation of $\mathrm{I} \kappa \mathrm{B} \alpha$, and present dose-dependence. Jointly using curcumin can decrease phosphorylation of IкB $\alpha$ (Fig. 4).

Chemotherapeutics induce apoptosis, jointly using curcumin induces apoptosis further by reducing Bcl-2 and Bcl-xL 
A

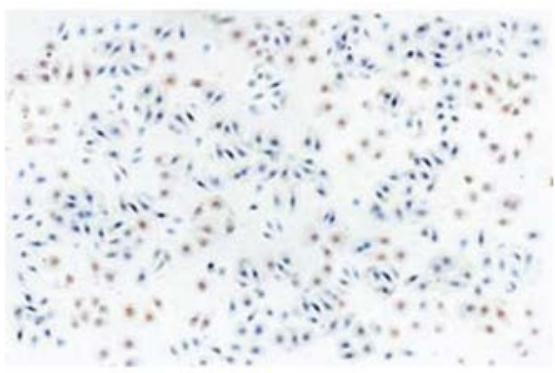

B

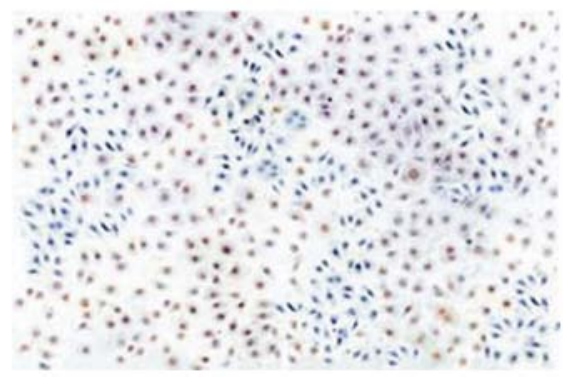

Figure 6. TUNEL was used to detect apoptosis. Positive signals were defined as presence brown color nuclear. (A) The apoptosis induced in cells treated by doxorubicin $(0.3 \mu \mathrm{mol} / 1)$ (x200). (B) The apoptosis induced in cells treated by doxorubicin $(0.3 \mu \mathrm{mol} / 1)+$ curcumin $(40 \mu \mathrm{mol} / 1$ pretreatment $)(\mathrm{x} 200)$.

levels. In our study, Annexin V/PI staining and TUNEL staining were both used to detect cell apoptosis. Since TUNEL staining has low sensitivity in distinguish apoptosis from necrosis, Annexin V/PI staining (Fig. 5) was used to analysis apoptosis. Morphological change of a single cell can be observed by TUNEL staining (Fig. 6), therefore the two methods were adopted. Both etoposide and doxorubicin induced apoptosis of SGC-7901 cells in a concentration dependent manner. Jointly using curcumin can induce apoptosis further.

One of the causes of chemoresistance is known to be upregulation of anti-apoptotic markers such as Bcl-2 and $\mathrm{Bcl}-\mathrm{xL}$, and this effect requires signaling through $\mathrm{NF}-\kappa \mathrm{B}$ $(16,17)$. To determine whether the sensitization of SGC-7901 to chemotherapeutic agents was due to the downregulation of NF- $\kappa \mathrm{B}$ and therefore, of Bcl-2 and Bcl-xL, we examined the levels of Bcl-2 and Bcl-xL. As Fig. 4 shows, the levels of $\mathrm{Bcl}-2$ and $\mathrm{Bcl}-\mathrm{xL}$ were reduced by combined use of curcumin. Thus, indicating that the mechanism of chemoresistance of SGC-7901 is due at least in part from the antiapoptotic effect of NF- $\kappa \mathrm{B}$-induced Bcl-2 and Bcl-xL. Together, these results confirm that the activation of $\mathrm{NF}-\kappa \mathrm{B}$ in gastric cells functions in an anti-apoptotic manner and is directly linked to the resistance of these cells to doxorubicin and etoposide.

\section{Discussion}

Chemotherapy is an important therapeutic modality for gastric cancer, however, the therapeutic efficacy of this method decreases when cancer cells develop resistance to chemotherapeutics. Block of cell apoptosis is the main reason of tumor cell resistance to chemotherapeutics. Several studies have suggested that activation of the transcription factor
$\mathrm{NF}-\kappa \mathrm{B}$ has been implicated in the protection of cells from apoptosis, and that the NF- $\mathrm{B}$-mediated survival signaling pathway play a critical role in cancer chemoresistance $(1,2,18)$. Thus, there is a need for novel strategies involving less toxic agents that can sensitize gastric cancer cells to chemotherapy. Curcumin, a component of turmeric, is one such agent that has been shown to suppress the NF- $\mathrm{B}$ and increased the efficacy of chemotherapeutics.

Curcumin, a spice common to India and the surrounding regions, is turmeric, being derived from the rhizome of Curcuma. Fractions of turmeric known as curcuminoids (curcumin, demethoxycurcumin, and bisdemethoxycurcumin) are considered the active compounds and possess a yellowish orange color. Curcumin is the primary curcuminoid being studied in a host of areas including antioxidant potential, inflammation, chemoprevention, and chemotherapy. Pre-clinical studies in a variety of cancer cell lines have consistently shown that curcumin possesses anti-cancer activity in vitro (19). Curcumin has been shown to suppress NF- $\kappa \mathrm{B}$ activation (12), downregulate the expression of NF- $\kappa \mathrm{B}$-regulated gene products with roles in anti-apoptosis and play an important role in increasing the efficacy of chemotherapeutics.

$\mathrm{NF}-\kappa \mathrm{B}$ is a family of dimeric transcription factors that control the expression of numerous genes involved in cell growth, regulation of apoptosis, and neoplastic transformation $(20,21)$. It was discovered in 1986 as a nuclear factor that binds to the enhancer region of the $\kappa \mathrm{B}$ chain of immunoglobulin in $\mathrm{B}$ cells. The Rel/NF- $\kappa$ B family comprises NF- $\kappa$ B1 (p50), NF- $\kappa$ B2 (p52), and the Rel proteins, RelA (p65), RelB, and c-Rel, which have a high level of sequence homology within their NH2-terminal 300 amino acids, the Rel homology domain. The most common dimer is the RelA (p65)/NF- $\mathrm{BB} 1$ (p50) heterodimer, i.e., NF- $\kappa \mathrm{B}$. In most unstimulated cells, $\mathrm{NF}-\kappa \mathrm{B}$ proteins are sequestered in the cytoplasm and are complexed with specific inhibitor proteins called $\mathrm{I} \kappa \mathrm{B}$ that render the $\mathrm{NF}-\kappa \mathrm{B}$ proteins inactive $(4,6)$. Stimulation of cells leads to phosphorylation and degradation of $\mathrm{I} \kappa \mathrm{B}$ and allows translocation of NF- $\kappa \mathrm{B}$ to the nucleus, resulting in expression of target genes. The transcription factor $\mathrm{NF}-\kappa \mathrm{B}$ has been implicated as an important mediator in several cellular processes from inflammation to cancer. In neoplasms, $\mathrm{NF}-\kappa \mathrm{B}$ has received specific attention for its role in oncogenesis (1-5). In addition, inducible chemoresistance is attributed to the activation of $\mathrm{NF}-\kappa \mathrm{B}$, which in turn stimulates the transcription of anti-apoptotic genes enabling cells to overcome chemotherapy-induced apoptosis $(15,16)$.

In our study, etoposide or doxorubicin suppressed the growth and induced apoptosis of SGC-7901 cells, activate $\mathrm{NF}-\kappa \mathrm{B}$ at the same time. Combined use of curcumin, it can induce apoptosis further and improve the curative effect of chemotherapy. The results indicated that curcumin potentiates the antitumor effects of chemotherapeutics. This effect was associated with downregulation of $\mathrm{NF}-\kappa \mathrm{B}$ activation and $\mathrm{NF}-\kappa \mathrm{B}$-regulated gene products.

$\mathrm{NF}-\kappa \mathrm{B}$ activation requires degradation of $\mathrm{I} \kappa \mathrm{B} \alpha$ to free $\mathrm{NF}-\kappa \mathrm{B}$ from the heterotrimeric $\mathrm{I} \kappa \mathrm{B} / \mathrm{NF}-\kappa \mathrm{B}$ complex and to translocate it into the nucleus. I $\kappa \mathrm{B} \alpha$ is the major endogenous inhibitor of $\mathrm{NF}-\kappa \mathrm{B}$ activation $(4,6,22)$. To further clarify the mechanism of activating $N F-\kappa B$ in gastric cancer chemotherapy, we focused on I $\mathrm{B} \alpha$ phosphorylation levels after various pharmacological intervention. In our 
study, chemotherapeutics have been shown to induce I $\kappa \mathrm{B} \alpha$ phosphorylation, degradation, and then $\mathrm{NF}-\kappa \mathrm{B}$ activation. Meanwhile, the effect of chemotherapeutics was attenuated by curcumin. To investigate whether curcumin can reverse chemoresistance by downregulating $\mathrm{NF}-\kappa \mathrm{B}$ in human gastric cancer cells through reducing anti-apoptotic genes, we examined the levels of Bcl-2 and Bcl-xL in our experiments. Our results show that curcumin can attenuate the levels of antiapoptotic genes Bcl-2 and Bcl-xL.

From these results, we consider that $\mathrm{NF}-\kappa \mathrm{B}$ pathway plays an important role in the chemoresistance and curcumin can reverse chemoresistance of gastric cancer cells. However, the function of $\mathrm{NF}-\kappa \mathrm{B}$ pathway on chemoresistance and the reversal of chemoresistance by downregulating $N F-\kappa B$ pathway in human gastric cancer cells remain controversial.

Work within last 10 years has shown that activation of $\mathrm{NF}-\kappa \mathrm{B}$ can suppress apoptosis induction by cytokines and chemotherapeutics (23-25). A large number of NF- $\mathrm{B}$ regulated genes that can abrogate apoptosis including TRAF1, TRAF2, cIAP1, cIAP2, XIAP, COX2, and surviving have been identified $(15,16,26)$. Paradoxically, however, most agents that activate NF- $\kappa \mathrm{B}$, also induce apoptosis. Thus, the activation of $\mathrm{NF}-\kappa \mathrm{B}$ has been shown to mediate chemoresistance. There are some other studies that suggest that $\mathrm{NF}-\kappa \mathrm{B}$ activation is either unrelated to apoptosis (27) or mediates apoptosis (28). For instance Mullerian-inhibiting substance (MIS) has been shown to activate $\mathrm{NF}-\kappa \mathrm{B}$, and this activation was shown to be essential for MIS-induced anti-proliferative effects against breast cancer cells (28). Similarily, taxol has been shown to induce apoptosis in human breast, ovarian, and epidermoid cancer cells, and this is mediated through the up-regulation of $\mathrm{I} \kappa \mathrm{B} \alpha$ kinase-mediated NF- $\kappa \mathrm{B}$ activation (29). Doxorubicin has been shown to activate both NF- $\kappa \mathrm{B}$ (30) and apoptosis (31). Moreover, several recent studies have challenged the notion that the induction of $\mathrm{NF}-\kappa \mathrm{B}$ leads to an anti-apoptotic response; the authors suggest that depending on the cellular context, $\mathrm{NF}-\kappa \mathrm{B}$ activation is required for chemotherapy to cause cell death. Also, it can be both an activator and repressor of its target genes, dependent upon the manner in which it is induced $(24,25,30,31)$. Therefore, delineating the role of $\mathrm{NF}-\kappa \mathrm{B}$ activation in specific tumors in response to clinically relevant chemotherapies is critical. Then, further analysis of the mechanisms behind the induction of NF- $\kappa \mathrm{B}$ could identify more effective targets for $\mathrm{NF}-\kappa \mathrm{B}$ inhibition strategies with the potential to improve cytotoxic response rates.

On the other hand, these differences could play a vital role in the outcome of cancer therapy in a clinical setting. It is possible that inhibition of $\mathrm{NF}-\kappa \mathrm{B}$ function as a mechanism of increasing the efficacy of current chemotherapy treatments might not be effective for all drugs used in all tumor types. The development of appropriate diagnostic indicators for the functional status of $\mathrm{NF}-\kappa \mathrm{B}$ in a cell could therefore become a valuable adjunct to $\mathrm{NF}-\kappa \mathrm{B}$ based cancer therapy.

In conclusion, our results demonstrate that curcumin potentiate the antitumor effects of chemotherapeutics by inhibiting $\mathrm{NF}-\kappa \mathrm{B}$ and its downstream targets with roles in anti-apoptosis. Since curcumin is very well tolerated in human subjects, even at very high doses (32), the combination of curcumin with chemotherapeutics has significant potential as an effective therapy for gastric cancer that can enhance the effect of chemo- therapeutics and overcome chemoresistance. Further clinical studies are necessary to confirm our findings in patients with gastric cancer.

\section{Acknowledgements}

This study was supported by the Foundation of Educational Committee Zhejiang Province, China, No. Y200909821; the National Natural Science Foundation of China, No. 30300154; the Qianjiang Scholars Foundation of the Ministry of Science and Technology of Zhejiang Province, China, No. 2008 R10022.

\section{References}

1. Edderkaoui M, Odinokova I, Ohno I, et al: Ellagic acid induces apoptosis through inhibition of nuclear factor kappa B in pancreatic cancer cells. World J Gastroenterol 14: 3672-3680, 2008.

2. Vega MI, Martínez-Paniagua M, Huerta-Yepez S, GonzálezBonilla C, Uematsu N and Bonavida B: Dysregulation of the cell survival/anti-apoptotic NF-kappaB pathway by the novel humanized BM-ca anti-CD20 mAb: implication in chemosensitization. Int J Oncol 35: 1289-1296, 2009.

3. Bhardwaj A, Sethi G, Vadhan-Raj S, et al: Resveratrol inhibits proliferation, induces apoptosis, and overcomes chemoresistance through down-regulation of STAT3 and nuclear factor-kappaBregulated antiapoptotic and cell survival gene products in human multiple myeloma cells. Blood 109: 2293-2302, 2007.

4. Gangadharan $C$, Thoh $M$ and Manna SK: Inhibition of constitutive activity of nuclear transcription factor kappaB sensitizes doxorubicin-resistant cells to apoptosis. J Cell Biochem 107: 203-213, 2009.

5. Ammann JU, Haag C, Kasperczyk H, Debatin KM and Fulda S: Sensitization of neuroblastoma cells for TRAIL-induced apoptosis by NF-kappaB inhibition. Int J Cancer 124: 1301-1311, 2009.

6. Yu LL, Dai N, Yu HG, Sun LM and Si JM: Akt associates with nuclear factor kappaB and plays an important role in chemoresistance of gastric cancer cells. Oncol Rep 24: 113-119, 2010.

7. Tas SW, Vervoordeldonk MJ and Tak PP: Gene therapy targeting nuclear factor-kappaB: towards clinical application in inflammatory diseases and cancer. Curr Gene The 9: 160-170, 2009.

8. Delgado JS, Mustafi R, Yee J, et al: Sorafenib triggers antiproliferative and pro-apoptotic signals in human esophageal adenocarcinoma cells. Dig Dis Sci 53: 3055-3064, 2008.

9. Arlt A, Gehrz A, Müerköster S, et al: Role of NF-kappaB and Akt/ PI3K in the resistance of pancreatic carcinoma cell lines against gemcitabine-induced cell death. Oncogene 22: 3243-3251, 2003.

10. Kamat AM, Tharakan ST, Sung B and Aggarwal BB: Curcumin potentiates the antitumor effects of Bacillus Calmette-Guerin against bladder cancer through the downregulation of NF-kappaB and upregulation of TRAIL receptors. Cancer Res 69: 8958-8966, 2009.

11. Kunnumakkara AB, Anand P and Aggarwal BB: Curcumin inhibits proliferation, invasion, angiogenesis and metastasis of different cancers through interaction with multiple cell signaling proteins. Cancer Lett 269: 199-225, 2008.

12. Hussain AR, Ahmed M, Al-Jomah NA, et al: Curcumin suppresses constitutive activation of nuclear factor-kappa B and requires functional Bax to induce apoptosis in Burkitt's lymphoma cell lines. Mol Cancer Ther 7: 3318-3329, 2008.

13. Campbell KJ, Witty JM, Rocha S and Perkins ND: Cisplatin mimics ARF tumor suppressor regulation of RelA (p65) nuclear factor-kappaB transactivation. Cancer Res 66: 929-935, 2006.

14. Wong BC, Jiang X, Fan XM, et al: Suppression of RelA/p65 nuclear translocation independent of I $\mathrm{B} \alpha \alpha$ degradation by cyclooxygenase-2 inhibitor in gastric cancer. Oncogene 22: 1189-1197, 2003.

15. Sosic D, Richardson JA, Yu K, Ornitz DM and Olson EN: Twist regulates cytokine gene expression through a negative feedback loop that represses NF-kappaB activity. Cell 112: 169-180, 2003.

16. Samanta AK, Huang HJ, Le XF, et al: MEKK3 expression correlates with nuclear factor kappa B activity and with expression of antiapoptotic genes in serous ovarian carcinoma. Cancer 115: 3897-3908, 2009. 
17. Lee TL, Yeh J, Friedman J, et al: A signal network involving coactivated NF-kappaB and STAT3 and altered p53 modulates BAX/BCL-XL expression and promotes cell survival of head and neck squamous cell carcinomas. Int J Cancer 122: 1987-1998, 2008.

18. Sung B, Kunnumakkara AB, Sethi G, Anand P, Guha S and Aggarwal BB: Curcumin circumvents chemoresistance in vitro and potentiates the effect of thalidomide and bortezomib against human multiple myeloma in nude mice model. Mol Cancer Ther 8: 959-970, 2009.

19. Aggarwal BB, Kumar A and Bharti AC: Anticancer potential of curcumin: preclinical and clinical studies. Anticancer Res 23: 363-398, 2003

20. Mustonen H, Puolakkainen P, Kemppainen E, Kiviluoto T and Kivilaakso E: Taurocholate potentiates ethanol-induced NF-kappaB activation and inhibits caspase-3 activity in cultured rat gastric mucosal cells. Dig Dis Sci 54: 928-936, 2009.

21. Nishida T, Yabe Y, Fu HY, et al: Geranylgeranylacetone induces cyclooxygenase-2 expression in cultured rat gastric epithelial cells through NF-kappaB. Dig Dis Sci 52: 1890-1896, 2007.

22. Karin M: Nuclear factor-kappaB in cancer development and progression. Nature 441: 431-436, 2006.

23. Beg AA and Baltimore D: An essential role for NF-kappaB in preventing TNF-alpha-induced cell death. Science 274: 782-784, 1996.

24. Wang CY, Mayo MW and Baldwin AS Jr: TNF- and cancer therapy-induced apoptosis: potentiation by inhibition of NF-kappaB. Science 274: 784-787, 1996.
25. Van Antwerp DJ, Martin SJ, Kafri T, Green DR and Verma IM: Suppression of TNF-alpha-induced apoptosis by NF-kappaB. Science 274: 787-789, 1996

26. Wang CY, Mayo MW, Korneluk RG, Goeddel DV and Baldwin AS Jr: NF-kappaB antiapoptosis: induction of TRAF1 and TRAF2 and c-IAP1 and c-IAP2 to suppress caspase- 8 activation. Science 281: 1680-1683, 1998.

27. Santos-Silva MC, Sampaio de Freitas M and Assreuy J: Killing of lymphoblastic leukemia cells by nitric oxide and taxol: involvement of NF-kappaB activity. Cancer Lett 173: 53-61, 2001.

28. Segev DL, Hoshiya Y, Stephen AE, et al: Mullerian inhibiting substance regulates NFkappaB signaling and growth of mammary epithelial cells in vivo. J Biol Chem 276: 26799-26806, 2001.

29. Segev DL, Ha TU, Tran TT, et al: Mullerian inhibiting substance inhibits breast cancer cell growth through an NFkappa B-mediated pathway. J Biol Chem 275: 28371-28379, 2000.

30. Boland MP, Foster SJ and O'Neill LA: Daunorubicin activates NFkappaB and induces kappaB-dependent gene expression in HL-60 promyelocytic and Jurkat T lymphoma cells. J Biol Chem 272: 12952-12960, 1997.

31. Kalivendi SV, Kotamraju S, Zhao H, Joseph J and Kalyanaraman B: Doxorubicin-induced apoptosis is associated with increased transcription of endothelial nitric-oxide synthase. Effect of antiapoptotic antioxidants and calcium. J Biol Chem 276: 47266-47276, 2001.

32. Bengmark S, Mesa MD and Gil A: Plant-derived health: the effects of turmeric and curcuminoids. Nutr Hosp 24: 273-281, 2009. 